ECONOMICS

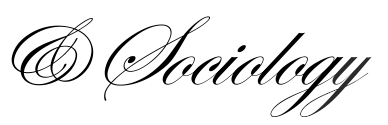

Agne Lauzadyte-Tutliene,

Vilnius University,

Vilnius, Lithuania,

E-mail:agne.lauzadyte@gmail.com

Tomas Balezentis,

Vilnius University,

Vilnius, Lithuania,

E-mail:tomas@laei.lt

Egle Goculenko,

Vilnius University,

Vilnius, Lithuania,

E-mail: eglegoculenko@gmail.com

Received: October, 2017

1st Revision: January, 2018

Accepted: February, 2018

DOI: $10.14254 / 2071-$

789X.2018/11-1/7

JEL Classification: B55, D60 I38
Lauzadyte-Tutliene, A., Balezentis, T., Goculenko, E. (2018). Welfare State in Central and Eastern Europe. Economics and Sociology, 11(1), 100-123. doi:10.14254/2071-789X.2018/11-1/7

\section{WELFARE STATE IN CENTRAL AND EASTERN EUROPE}

\begin{abstract}
This study aims at analyzing the existing welfare state models in Europe and investigating welfare regimes in the countries of Central and Eastern Europe. The hierarchical cluster analysis, employed in this study, revealed that five welfare state models can be distinguished in this region. The analysis also revealed that Central and Eastern European countries are too diverse to form a single cluster, and thus two models of the welfare state the Eastern Europe welfare model and the Central Europe welfare model - could be distinguished. Meanwhile, while investigating the situation of Central and Eastern European countries in the more general European context, it was observed that Central European welfare model is closer to the old European countries, while the Eastern European welfare model is very different from all other models.
\end{abstract}

\title{
Introduction
}

Investigation of the welfare state as a phenomenon began in the middle of the $20^{\text {th }}$ century, however, quality of life remains to be a relevant topic today (Bartkowiak-Bakun, 2017). Reduction of social marginalization and income inequality, and ensuring prosperity for each member of society are the main objectives of the welfare state (Khouri et al., 2017; Draskovic, 2017; Beg et al., 2017; Calinescu et al., 2018). Therefore, welfare state is often associated primarily with Scandinavian countries with their very well developed systems of social benefits.

However, shared values and interaction between the market, the family and the state are equally important. Based on the chosen social policies aimed at reducing inequalities in society, a certain model of welfare state can be assigned to the state. Despite the significant interest of scientists, there is no single and clear way to investigate the existing model of welfare state in each country. And particularly, very little attention has been paid to the analysis of welfare state in Central and Eastern European countries.

The global financial crisis which began back in 2007 has been a challenge for welfare states and has led a number of governments to the decision to review their social policies. 
Changes in the volumes of social benefits and/or their provision rules as well as demographic situation have affected further development of the welfare state (Meyer et al., 2017; Ushakov et al., 2017).

This study aims at analyzing the existing welfare state models (Draskovic et al., 2017) in Europe and investigating welfare regimes in the countries of Central and Eastern Europe.

The hierarchical cluster analysis, employed in this study, has revealed that five welfare state models can be distinguished in Europe. The analysis also revealed that Central and Eastern European countries are too diverse to form a single cluster, and thus two models of the welfare state - the Eastern European welfare model and the Central European welfare model - could be distinguished.

While investigating the situation of Central and Eastern Europe countries in the general European context, it was observed that the Central Europe welfare model is closer to the old European countries, while the Eastern Europe welfare model is very different from all the other welfare state models.

The structure of the paper is as follows. Section 1 presents the literature review. Section 2 explains the suggested research methodology. Section 3 is dedicated to the results of cluster analysis, while section 4 compares Eastern and Central European welfare state models.

\section{Literature review}

British scholar Richard M. Titmuss, who in the late 1960s presented welfare states classification scheme and distinguished the Residual, the Industrial AchievementPerformance, and the Institutional Redistributive welfare models (Titmuss, 1974) is generally considered to be the pioneer of the social policies modeling. In the countries of the residual model, families are given priority and the state intervenes only in the extreme cases when the family itself can no longer take care of its well-being. In the welfare state of production, a significant role is played by the social welfare institutions that provide support in terms of performance and productivity, while the institutional redistributive welfare model provides social services based on the need, seek social equality.

However, the greatest impact on the further research of the welfare states had Danish sociologist's Gosta Esping-Andersen's classification, which was based on decommodification and stratification criteria. Decommodification here reflects the degree to which individuals can maintain a socially acceptable standard of living without market intervention, i.e. the more favorable the possibility of receiving state social benefits or other state support, the higher is the level of decommodification; while stratification means the division of society into social strata by income level, education, social status or other characteristics (EspingAndersen, 1995). This scholar, based on the relationship between the state, the market and the family, distinguished three theoretical models of the welfare state: the Liberal, the Conservative-corporatist and the Social democratic.

In the classification above, the liberal model is characterized by low social benefits for the poor, while the preference is given to the market. As state social benefits are modest, the level of decommodification in the liberal model is low. This results marginalization between the poor and the wealthy, and therefore stratification in terms of income is evident.

In the second, conservative-corporate, type of welfare regime the priority is given to the church and the family, while the private wealth creation becomes less significant. The significance of the state social benefits in this model is lower than in that of the liberal type, and therefore the level of decommodification is moderate. The social insurance system is oriented towards the individuals of various occupations and allocates the sickness and unemployment benefits, the pensions and the other cash benefits accordingly, i.e. the social 
insurance system is based on the merit principle. However, in support of the traditional family, in which maternity is supposed to be the main task of women, there is a lack of day care centers and similar types of services to ensure equal opportunities between men and women, while the support is provided to family only when it's no longer able to take care of itself. Thus, in the conservative-corporate type of the welfare state, the population is divided not only according to achievements, but also gender-based (Esping-Andersen, 1995).

In the third, social democratic, welfare model, the preference is given to equality, while the state seeks to ensure the high living standards for all members of the society. The concept of equality in this welfare regime is perceived widely, i.e. it's not only limited to income equality, but focuses on equal opportunities and equal treatment. Unlike in the liberal or conservative-corporate models, the social assistance does not remain as the last income source for those who can no longer take care of themselves, but it is provided as a preventive measure. However, the high standards of living and generous benefits result high taxes, thus, it is extremely important to ensure low unemployment rate. Due to the high influence of the state, the level of decommodification is high.

Esping-Andersen tested these theoretical models by conducting an empirical study of three social welfare programs: pensions, sickness benefits and unemployment benefits (Esping-Andersen, 1995). After analyzing the 18 Member States of the Organization for Economic Co-operation and Development (OECD), the author attributed them to the Liberal, the Conservative-corporatist or the Social democratic model of welfare state.

Although the classification of the welfare states by Gosta Esping-Andersen served as the basis for further research, the method chosen by the author got some criticism. The critics argue that it is inappropriate to rely solely on cash benefits when a welfare state also includes various social services such as science or medicine (Bambra, 2005; Dacko-Pikiewicz and Walancik, 2016; Stefko et al., 2017). Bambra conducted a study based on the EspingAndersen analysis, including health care services into research. After analyzing the same 18 countries, it has been observed that some of them cannot be assigned to the traditional three models and they do form the separate subgroups. In this way, the author distinguished five models of welfare state: the Liberal, the Conservative, the Social democratic, the Liberal type subgroup and the Conservative type subgroup.

Further research has been conducted by the other authors as well. The typology by Korpi \& Palme (1998) is based on the institutional characteristics of welfare state - the oldage pensions and sickness benefit programs. The authors investigate the institutional structure of these programs based on several aspects:

- What is the basis of citizen's right to receive benefits / pensions (i.e., based on the need, contributions, citizenship, membership of a certain professional category etc.);

- What should be the level of social insurance benefits that would replace lost income (the minimum level, the same level or based on income received);

- How the social insurance program is regulated (i.e., whether employers and employees collaborate in managing the program).

Five possible welfare state models of the welfare state - the Target, the Corporate, the Basic protection, the Encompassing and the Voluntary subsidized - have been distinguished based on the aspects above (Korpi \& Palme, 1998). No countries have been assigned to the fifth theoretical model, therefore, it will not be discussed in more detail in this paper. The authors pointed out that in the Target model countries, the social benefits are based on the need and are only paid for the poor or disadvantaged, while the state almost does not interfere.

In the countries of the Basic protection welfare model, the right to social assistance is based on the contributions paid or citizenship (place of residence). In these countries, as in the case of the target model, the role of the state is modest and the market is left free to act. Thus, it could be assumed that the Target and the Basic protection models in Korpi \& Palme 
classification correspond to the Liberal model distinguishes by Esping-Andersen. However, Korpi \& Palme the study shows that Esping-Andersen's classification was inaccurate, i.e. the author erred in defining the different welfare models as one.

The Corporate model highlights the cooperation between the employees and employers in the management of social policy, and therefore entitlement to benefits depends on paid contributions and employment, i.e. the principle of merit is applicable (Korpi \& Palme, 1998). Due to the major attention to economically active individuals and stratification of the society based on employment, this model resembles the Conservative-corporatist type of welfare state distinguished by Esping-Andersen.

In the countries of the fourth, Encompassing, model, the right to social protection is based on contributions and citizenship, so all citizens have equal rights to participate in the same programs (Korpi \& Palme, 1998). In the countries of the Encompassing model inequality is minimum and distribution of income is maximum, it can therefore be said that it complies with the Social-democratic model of Esping-Andersen.

The second argument of the critics as to why the Esping-Andersen model is inaccurate, is that the nature and diversity of the countries selected for the model may determine inappropriate classification of the countries (Arts \& Gelissen, 2003; Rhodes, 1996). The critics pointed out that Esping-Andersen did not attribute South European countries to a separate Mediterranean or South-European model, but rather opted for one country from this region - Italy - and attributed it to the Conservative-corporatist welfare state (Saint-Arnaud \& Bernard, 2003). It is recognized that although the Conservative-corporatist and Mediterranean models are quite similar, there are several fundamental differences between them.

Saint-Arnaud \& Bernard (2003) note that in the Latin welfare states the administrative expenditure of the public sector is more limited than in the conservative states, but is higher than in the Liberal type states. Their research revealed that in the Latin welfare states, compared to Liberal, Social- democratic and Conservative welfare states, least investment is made into health care, education and vocational training. These states can be characterized by high level of unemployment, which among women is higher even than in the Conservative welfare states.

Rhodes (1996) points out that the distribution of income in the Mediterranean states has frequently been determined by pressure from influence groups, meanwhile corruption which exists in these states increases the gap between the rich and the poor. The author further notes that clientelism reduces the effectiveness of the government sector and increases undisciplined spending (Androniceanu, Popescu CR, 2017). Due to such situation, income inequality in the Mediterranean countries is high.

Sapir (2006) also agrees with the existence of the Mediterranean welfare state model. The author identifies four welfare state models: Nordic, Anglo-Saxon, Continental and Mediterranean. The Nordic model identified by Sapir (2006) coincides with EspingAndersen's Social-democratic model, because expenditure for social protection in the countries of this model is the highest and there is an active policy of reducing unemployment. In the Anglo-Saxon countries social assistance is provided as the last resort, therefore the model may be equivalent to the Liberal welfare state model. In the Continental welfare state model great attention is paid to unemployment benefits and old age pensions, therefore, this model could be linked to Esping-Andersen's Conservative-corporatist model.

According to Sapir (2006), the Mediterranean welfare states focus their social spending on old age pensions, which is the characteristic of the Conservative-corporatist welfare state model. However, the author notes that the redistribution of income in order to reduce income inequality and poverty is the smallest in the Mediterranean states compared with other models examined by the author. In addition, these states maintain high levels of 
employment protection and quite low benefits to the unemployed (Sapir, 2006; Soede et al., 2004).

Esping-Andersen did not include Central and Eastern European countries in his research either, so in this respect the classification of welfare states could have been inaccurate. It is quite difficult to allocate the countries of this region to a single model, because they differ from one another (Fenger, 2007). Some countries have advanced considerably and are members of the European Union, while others are still in a transitional period.

The analysis carried out by McMenamin (2003) has showed that in addition to the Social-democratic, Liberal and Conservative models, there is the East-Central European welfare state model. According to the author, these states differ considerably in terms of their political characteristics. The Czech Republic, Hungary and Poland are classic examples of democracy, as one-party governments in these countries are rare and the coalitions in power are vivid. However, pluralistic rather than corporate interest groups dominate. Each of these countries are fairly centralized, but have independent central banks. The majority of the measures are aimed at the generous welfare that reduces the importance of the market and puts the state before the market.

Still, social transfers in the Eastern-Central European countries are quite small (McMenamin, 2003). There is greater gender discrimination in these countries as women are less included, their employment levels are lower and there are gender pay gaps. The author notes high social insurance contribution rates for employers as one of the most prominent features in these welfare states. McMenamin's research has revealed that the industrial sector in the East Central European countries is more developed, creates more jobs and added value than the services sector. The author observes that the importance and development of the agricultural sector differ across these countries and there are huge differences in this area.

Fenger (2007) included more countries in his research and found that Eastern European countries differ from other countries and can form a separate welfare state mode (Becerra-Alonso et al., 2016). The cluster analysis performed by the author showed that Eastern European countries should be attributed to a separate welfare state model, which could be subdivided into three types: former USSR, post-Communist-European and developing welfare states.

According to Fenger (2007), in terms of government spending the former USSR countries could be attributed to the Conservative type, yet all other variables of the government programs analyzed by the author fall behind those of the Western European countries. The author identifies high levels of mistrust and differences in the variables of the social situation examined by the author (income inequalities, women involvement, GDP growth, inflation and demographic indicators) as essential differences between the former USSR countries and countries of other types.

Soede et al. (2004) admit that there are more than three models of the welfare state and identify five models: Scandinavian, Continental, Anglo-Saxon, Mediterranean and Eastern European region. Based on the analysis carried out by the authors, unemployment benefits, disability allowances, allowances for children and pensions are considerably lower in the Eastern European countries than in other European countries. However, government revenues in these countries are also smaller thus limiting provision of adequate social assistance to the population. East European countries mostly rely on the contribution-based pension system, due to which pensions may decrease, if the governments are not able to manage the public sector finances (Novickytè, Rabikauskaitè, 2017).

Summarizing the literature review it could be noted that the inclusion of broader range of European countries into the study and choosing appropriate indicators makes it possible to distinguish more than three classic welfare state models. Thus, the investigation of the welfare 
states would be more accurate and this would lead to a proper comparison between the models.

\section{Methodological approach}

The method of hierarchical cluster analysis, which is aimed at grouping countries into the different groups - clusters - is employed for the research. It should be noted that the cluster analysis method was used by McMenamim (2003), Saint-Arnaud \& Bernard (2003) and other scholars.

In a hierarchical cluster analysis, the countries are divided into groups, and a graphical representation - dendogram - is presented (Małkowska and Głuszak, 2016). This method is convenient as the dendogram shows not only the main groups but also close subgroups of the countries (Mačerinskienė and Aleknavičiūtè, 2017).

Based Fenger (2007), the Euclidean square-distance indicator is selected, which, among cases, determines the distance of the subjects in the axis. The Ward method is used for grouping the cases, which reduces the dispersion in groups and increases their homogeneity (Fenger, 2007). The variables are standardized in the analysis, selecting their values in the interval between -1 and 1 .

The literature review revealed that there are five main welfare models in Europe: the Liberal, the Scandinavian, the Conservative, the Southern Europe and the Eastern Europe. Therefore, in order to avoid the inappropriate determination of the number of clusters and taking into account the results of the literature review, this cluster analysis indicates that there may be a maximum of six clusters.

One of the aspects of the success of the cluster analysis is the creation of an optimal list of countries. This study seeks to assign countries as precisely as possible to a specific welfare state model, so the selected countries are from different European regions: the Baltic States, the Scandinavian countries, the Western Europe and other regions (Table 1).

Table 1. European Countries for Cluster Analysis (created by the authors)

\begin{tabular}{ccc}
\hline & Countries & \\
\hline Ireland & United Kingdom & Portugal \\
\hline Austria & Cyprus & France \\
\hline Belgium & Croatia & Romania \\
\hline Bulgaria & Latvia & Slovakia \\
\hline Czech Republic & Poland & Slovenia \\
\hline Denmark & Lithuania & Finland \\
\hline Estonia & Luxembourg & Sweden \\
\hline Greece & Malta & Hungary \\
\hline Spain & The Netherlands & Germany \\
\hline Italy & Norway & - \\
\hline
\end{tabular}

Due to a lack of data in the database of the European Union Statistical Office (Eurostat), this study will not address Switzerland and Iceland. Thus, 29 European countries have been chosen for cluster analysis.

The variables used in this research are divided into four groups: government program variables, political situation variables, economic situation variables and social situation variables.

Political situation variables. The assessment of a state's political situation is one of the most complex because of its specifics. It should be noted that the political influence is 
difficult to measure and often there is a lack of data and uncertainty in this area (Pilc, 2017). Therefore, after analyzing the political indicators published by Eurostat and their possible application for cluster analysis, it was decided to use only one indicator - the electoral activity at the national and European elections.

This study is based on 2014 data, but the elections were held at different times in the countries in question, so if there is no country's voter turnout indicator for 2014, the next most recent indicator is used. Further details on voter turnout are given in Table Al.

Economic situation variables. The social and economic situation variables are closely interrelated. Although Fenger (2007) has classified the real GDP growth and inflation as social variables in his study, in this study they are classified as economic indicators. The Harmonized Index of Consumer Prices (HICP) is used to measure inflation. The methodology for calculating this indicator is consistent with all the countries of the European Union, so it can be concluded that the data provided by Eurostat are correct and unambiguous. Based on McMenamin (2003) analysis, the shares of exports and imports in GDP are used to assess the economic situation. The economic indicators of the countries in question are presented in Table A2.

Social situation variables. This group of variables is the largest and includes indicators describing the general situation in the labor market, gender differences in the labor market, demographic situation, education of the population and living conditions (Figure 1).

\begin{tabular}{|c|c|c|}
\hline $\begin{array}{l}\text { Demographic } \\
\text { situation }\end{array}$ & Education & Labor market \\
\hline $\begin{array}{l}\text { - infant } \\
\text { mortality } \\
\text { - life expectancy } \\
\text { - birth rate }\end{array}$ & $\begin{array}{l}\text { - four-year-olds } \\
\text { in educational } \\
\text { institutions } \\
\text {-20-24 years } \\
\text { old students in } \\
\text { tertiary } \\
\text { education } \\
\text {-25-64 years } \\
\text { old persons } \\
\text { with at least } \\
\text { secondary } \\
\text { education } \\
\text {-premature } \\
\text { school leaving }\end{array}$ & $\begin{array}{l}\text {-employment } \\
\text {-youth } \\
\text { employment } \\
\text { - employment of } \\
\text { the elders } \\
\text { - workers under } \\
\text { temporary } \\
\text { contracts } \\
\text { - part-time } \\
\text { employees } \\
\text { - self-employed } \\
\text { - long term } \\
\text { unemployment } \\
\text { - unemployment } \\
\text { rate }\end{array}$ \\
\hline
\end{tabular}

\begin{tabular}{|c|c|}
\hline $\begin{array}{l}\text { Gender differences } \\
\text { in the labor market }\end{array}$ & $\begin{array}{l}\text { Living } \\
\text { conditions }\end{array}$ \\
\hline $\begin{array}{l}\text { - the ratio of } \\
\text { employment } \\
\text { rates of men and } \\
\text { women } \\
\text { - the ratio of } \\
\text { unemployment } \\
\text { rates of men and } \\
\text { women } \\
\text { - the ratio of long } \\
\text { term } \\
\text { unemployment } \\
\text { rates of men and } \\
\text { women } \\
\text { - the pay gap } \\
\text { between men } \\
\text { and women }\end{array}$ & $\begin{array}{l}\text { - people at risk } \\
\text { of poverty and } \\
\text { social } \\
\text { exclusion } \\
\text { - aggregated } \\
\text { replacement } \\
\text { rate } \\
\text { - income } \\
\text { inequality }\end{array}$ \\
\hline
\end{tabular}

Figure 1. Social situation variables (created by the authors)

The ratio of income of the richest $20 \%$ of the population and the poorest $20 \%$ the population (or S80/S20 ratio) is used in the cluster analysis as income inequality measure.

It should be noted that Fenger (2007) included only unemployment rate into analysis, but this paper analyzes more labor market indicators to take into account the situation of women and men in the labor market and types of employment contracts. One of the variables is long-term unemployment, which reflects the long term unemployment burden in the country. Detailed indicators of the social situation are presented in Appendix Tables A3 to A6.

Government programs. The variables of government programs reflect the spending to the various fields, thus they are helping to assess the economic and social situation in the country, and the policies. Education, social protection, health and research are especially 
sensitive areas, and it is expected that there will be sufficient funds allocated to these areas in the ideal welfare state. The details of the government expenditure are presented in Table A7.

The relative indicators are used in this research for the comparison of variables as the size of the countries differ. For example, some indicators of the government programs are expressed as a fraction of GDP, while the others - as a fraction of the general government expenditure.

\section{Results of the cluster analysis}

Based on the agglomeration schedule, it can be seen that the situation is best reflected by the five clusters, since the difference between the fifth and the sixth cluster is relatively small (Figure 2). In addition, it can be seen that by selecting countries to be divided into six groups, the sixth cluster would only include Ireland (Table 2). So the optimal number of clusters is five.

Coefficient

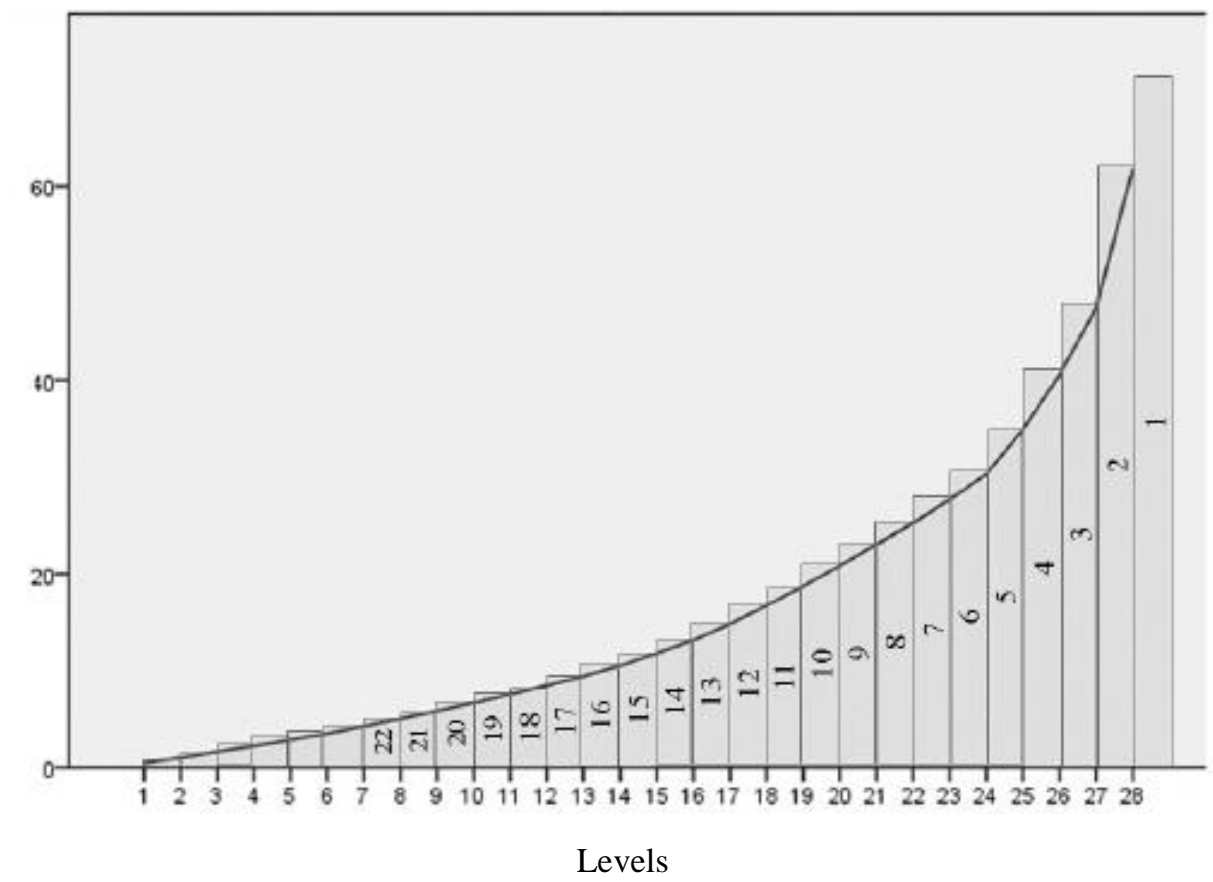

Figure 2. Agglomeration schedule (created by the authors)

The cluster analysis of the selected European countries based on economic, social, political and government program variables is presented in Table 2. Table 2 shows that in the case of five clusters, one cluster consists of Greece, Spain, Italy, Cyprus and Portugal. This result is confirmed by Saint-Arnaud \& Bernard (2003), Soede et al. (2004) and Sapir (2006) studies, where the Mediterranean welfare, or the Latin region, model has been distinguished. In this study, the countries in question belong to the Mediterranean welfare model.

The second cluster (Table 2) consists of the old European countries: Austria, Belgium, Denmark, the United Kingdom, the Netherlands, Norway, France, Finland, Sweden and Germany. According to Fenger (2007), Esping-Andersen (1995), Korpi \& Palme (1998), Saint-Arnaud \& Bernard (2003) and other authors, these countries should form three separate models, but they form one group based on selected variables. These results show that the concept of welfare state among the old European countries is similar, but is very different 
from the concept of the welfare state in the Mediterranean and other countries covered by this study.

The small European countries - Luxembourg and Malta - form the third cluster (Table 2). These countries are exceptional, and if we think that there are not five, but four clusters in Europe, they would still constitute one separate cluster.

Table 2. Classification of countries based on different number of clusters (created by the authors)

\begin{tabular}{lccccc}
\hline & 6 clusters & 5 clusters & 4 clusters & 3 clusters & 2 clusters \\
\hline 1: Austria & 1 & 1 & 1 & 1 & 1 \\
\hline 2: Belgium & 1 & 1 & 1 & 1 & 1 \\
\hline 3: Bulgaria & 2 & 2 & 2 & 2 & 2 \\
\hline 4: Czech Republic & 3 & 3 & 3 & 3 & 2 \\
\hline 5: Denmark & 1 & 1 & 1 & 1 & 1 \\
\hline 6: Estonia & 2 & 2 & 2 & 2 & 2 \\
\hline 7: Greece & 4 & 4 & 3 & 3 & 2 \\
\hline 8: Spain & 4 & 4 & 3 & 3 & 2 \\
\hline 9: Italy & 4 & 4 & 3 & 3 & 2 \\
\hline 10: United Kingdom & 1 & 1 & 1 & 1 & 1 \\
\hline 11: Cyprus & 4 & 4 & 3 & 3 & 2 \\
\hline 12: Croatia & 3 & 3 & 3 & 3 & 2 \\
\hline 13: Latvia & 2 & 2 & 2 & 2 & 2 \\
\hline 14: Poland & 3 & 3 & 3 & 3 & 2 \\
\hline 15: Lithuania & 2 & 2 & 2 & 2 & 2 \\
\hline 16: Luxembourg & 5 & 5 & 4 & 3 & 2 \\
\hline 17: The Netherlands & 1 & 1 & 1 & 1 & 1 \\
\hline 18: Norway & 1 & 1 & 1 & 1 & 1 \\
\hline 19: Portugal & 4 & 4 & 3 & 3 & 2 \\
\hline 20: France & 1 & 1 & 1 & 1 & 1 \\
\hline 21: Romania & 2 & 2 & 2 & 2 & 2 \\
\hline 22: Slovakia & 3 & 3 & 3 & 3 & 2 \\
\hline 23: Slovenia & 3 & 3 & 3 & 3 & 2 \\
\hline 24: Finland & 1 & 1 & 1 & 1 & 1 \\
\hline 25: Sweden & 1 & 1 & 1 & 1 & 1 \\
\hline 26: Hungary & 3 & 3 & 3 & 3 & 2 \\
\hline 27: Germany & 1 & 1 & 1 & 1 & 1 \\
\hline 28: Ireland & 6 & 2 & 2 & 2 & 2 \\
\hline 29: Malta & 5 & 5 & 4 & 3 & 2 \\
\hline
\end{tabular}

The small European countries are more open to trade, compared with the old European countries. These models also differ in the fact that the small European countries spend less on research and development. In addition, based on the 2014 data, the GDP in the small European countries grew faster than in the old Europe. These essential differences from the 
old European countries bring the cluster of the small European countries closer to the south and east of Europe.

It is obvious that Luxembourg and Malta differ much one from another, thus, the additional research and more in-depth analysis is required. However, this paper focuses on welfare state in Eastern Europe, therefore no further investigation of Malta and Luxembourg is being carried out in this study.

The countries of Central and Eastern Europe split into two clusters (Table 2), and the first of them - the Eastern Europe welfare model - includes Lithuania, Latvia, Estonia, Bulgaria, Romania and Ireland. Attention is drawn to the fact that Ireland was hit hard by the economic crisis of 2008, which led the government to significantly reduce costs and save money in various areas. For example, government spending on health only slightly increased in 2015 in Ireland - for the first time in six years (Burke et al., 2016). Taking into account the situation in Ireland during the economic crisis and the difficult recovery of the country, Ireland's membership in the Eastern Europe welfare model is questionable, and this country is not being investigated further.

The Czech Republic, Croatia, Poland, Slovakia, Slovenia and Hungary belong to the Central Europe welfare model, and the dendogram shows that the Mediterranean welfare state model is closest to it. Nevertheless, these two models have some fundamental differences. The life expectancy is longer and a larger proportion of students prematurely leave education institutions in the Mediterranean welfare states (Append Tables A3 and A4). There is also higher GDP growth in the Central Europe welfare model, but the latter region was more affected by the economic crisis of 2008 (Table A2). However, despite the differences, these models are rather similar and could form a single cluster.

The cluster of Eastern European countries would remain separate even if it were assumed that there are three clusters in Europe, thus, this model of welfare state is very different from the rest. While if we assume that there are two welfare state models in Europe, the first one would include the old European states, and the second one - all the other states examined, i.e. the Mediterranean countries, the Central and Eastern European countries and the Small countries.

Thus, the hierarchical cluster analysis revealed that five welfare state models can be distinguished in Europe. The analysis also revealed that Central and Eastern European countries are too diverse to form a single cluster, and thus two separate models of the welfare state - the Eastern Europe welfare model and the Central Europe welfare model - could be distinguished. It is also evident that the Eastern Europe welfare model is very different from all the other welfare state models. Taking into account such results of the cluster analysis, it is important to examine the main differences between the two welfare models of Central and Eastern Europe countries.

\section{Comparison of the Central and Eastern Europe welfare state models}

The main indicators which distinguished the Central and Eastern Europe into two models in the hierarchical cluster analysis are presented in Table 3. Firstly, it is evident that income inequality, measured by the ratio of income of the richest $20 \%$ of the population and the poorest $20 \%$ the population, is higher in the countries of the Eastern Europe welfare model, compared with the Central Europe welfare states. On average, this ratio in the Central Europe equals to 4.2, while in the Eastern Europe it comes up to 6.6 (Table 3). The highest income inequality in terms of the indicator is observed in Romania, and it should be noted that this country is lagging behind the other Central and Eastern European countries based on the other indicators such as infant mortality or early school leaving (Tables A3-A4). 
Also, in the Central Europe welfare model, a larger proportion of workers work under the temporary employment contracts, i.e. on average by 9.8 per cent more, compared with the Eastern Europe welfare model (Table 3). The temporary employment contracts are often assessed controversially, but they are believed to act as a mitigating measure during a recession, to allow negotiation for better remuneration and to foster productivity (Koutentakis, 2008; Addessi, 2014). It is recognized that the existence of the temporary employment contracts reflects labor market flexibility (Malo \& Cueto, 2013).

Table 3. Differences between the Central and Eastern Europe Welfare Models (created by the authors based on Eurostat data)

\begin{tabular}{lccccc}
\hline & $\begin{array}{c}\text { Income } \\
\text { inequality } \\
(\text { S80/S20 } \\
\text { ratio })\end{array}$ & $\begin{array}{c}\text { Workers under } \\
\text { temporary } \\
\text { contracts as a } \\
\text { share of labor } \\
\text { force }\end{array}$ & $\begin{array}{c}\text { Ratio of } \\
\text { unemployment } \\
\text { rates of men } \\
\text { and women }\end{array}$ & $\begin{array}{c}\text { Government } \\
\text { expenditure } \\
\text { as a share of } \\
\text { GDP }\end{array}$ & $\begin{array}{c}\text { Social } \\
\text { contributions } \\
\text { as a share of } \\
\text { GDP }\end{array}$ \\
\hline Bulgaria & 6.8 & 4.6 & 1.18 & 42.1 & 7.9 \\
\hline Estonia & 6.5 & 2.8 & 1.16 & 38.0 & 11.1 \\
\hline Latvia & 6.5 & 2.9 & 1.20 & 37.3 & 8.7 \\
\hline Lithuania & 6.1 & 2.4 & 1.33 & 34.8 & 11.5 \\
\hline Romania & 7.2 & 1.1 & 1.20 & 34.9 & 8.6 \\
\hline Group average & 6.6 & 2.8 & 1.21 & 37.4 & 9.6 \\
\hline The Czech Republic & 3.5 & Central Europe welfare model & & \\
\hline Croatia & 5.1 & 14.4 & 0.69 & 42.6 & 14.8 \\
\hline Poland & 4.9 & 22.4 & 0.90 & 48.2 & 11.8 \\
\hline Slovakia & 3.9 & 7.4 & 0.89 & 42.1 & 13.2 \\
\hline Slovenia & 3.7 & 13.7 & 0.94 & 41.6 & 13.6 \\
\hline Hungary & 4.3 & 9.6 & 0.85 & 49.8 & 14.6 \\
\hline Group average & 4.2 & 12.6 & 0.96 & 49.9 & 13.1 \\
\hline
\end{tabular}

It needs to be noted that only in the Eastern Europe welfare model the share of workers under temporary contracts is less than 5 per cent of the labor force (Table A5) and this suggests that the labor market in these countries is not flexible.

Another indicator which splits the Eastern and Central Europe into two welfare state models is government expenditure, which is lower by 8.2 per cent in the Eastern Europe welfare model, compared with the other model investigated (Table 3).

The largest share, i.e. 31.9 per cent, of government expenditure is allocated to social protection in the Eastern Europe welfare model, but this is still less by 8.5 per cent, compared with the EU-28 average, while the most generous social protection expenditure were observed in the old European countries, especially in Denmark, France, Finland (Table A8).

In the Eastern Europe welfare model, on average, 13 per cent of the expenditure goes to education, the economy (i.e.: transport, fuel and energy, agriculture and other economic areas), health and general public services. However, some differences could be found while analyzing each state of the model. For example, the expenditure to the economy ranges from 9.3 per cent in Lithuania up to 17.1 per cent in Romania. Investments are needed to improve infrastructure in order to achieve a higher level of development, thus, even inside the same welfare model the structure of expenditure can vary radically and it depends on governments' priorities. 
The least attention is paid to environment protection in the Eastern Europe welfare model, i.e. the smallest fraction, or on average 1.8 per cent, of government expenditure is allocated to this sector in the countries belonging to this model. The figures, however, range from 1.6 per cent in Bulgaria, Estonia and Lithuania to 2.2 per cent in Romania. These results provide two basic insights. Firstly, although the economy of the states of the Eastern Europe welfare model grows on average 1.2 per cent faster than in the old European countries (Table A2), a very low share of the expenditure for environment raises questions about whether such growth is sustainable (Szyja, 2016). Secondly, the state of the environment is not evaluated properly.

In the Central Europe welfare model, about 1.9 per cent of government expenditure is allocated to environment protection, i.e. about 0.1 per cent more than in the Eastern Europe welfare model (Table A8). However, the lowest fraction of the expenditure in this welfare model goes to housing (1.7 per cent), while the highest share - as in the case of the Eastern Europe - is allotted to the social protection, and it varies from 31.1 per cent in the Czech Republic up to 48.1 per cent in Slovakia. It should be noted that the expenditure to the social protection in Slovakia is the highest, compared with the rest of the countries researched (Table A8).

Approximately 12.6 per cent of government expenditure is allotted to the economy in the Central Europe welfare model, which is by 0.2 per cent less than in the case of Eastern Europe. However, in the other models distinguished by this study, this share is even lower (Table A8).

It is also obvious that the social contributions amounted to 9.6 per cent of GDP in the Eastern Europe welfare model, while the corresponding figure came up to 13.5 per cent of GDP in the Central Europe (Table 3). The government expenditure correlates with the income received, so it is obvious that, when it comes to collecting less income from social contributions, it is not possible to implement a generous social policy. Given that social protection expenditure represents a significant part of government spending, it is worth investigating the structure of these costs.

The highest share of the social protection expenditure falls on old-age pensions in both the Eastern and the Central Europe models. It should be noted that in the Eastern Europe welfare model, the share of the old age pensions expenditure came up to 20.9 per cent of the total social protection expenditure, while in the Central Europe welfare model this figure equaled to 17.9 per cent (Table A9).

However, a higher proportion of social protection expenditure is allocated to sickness and disability benefits in the Central Europe welfare model. Usually up to 10 per cent of the government expenditure is allocated to this category, except Croatia, Slovakia, the Netherlands and Norway with the proportions of $10.3 \%, 17.9 \%, 10.2 \%$ and $13 \%$ respectively (Table A9). Thus, when analyzing the structure of the social protection expenditure in the two models under considerations, different priorities could be observed in pursuit of the social policy objectives.

After examining the differences between the two models under consideration it could be argued that the Central Europe welfare model states are more advanced and closer to the rest of Europe or the old European states than the Eastern Europe welfare model countries. In the Eastern Europe, there is a rigid and discriminatory labor market and lower government financial capacities to pursue generous social policies.

Although the analysis revealed that the majority of funds are allocated to the social protection in both the models under consideration, this expenditure share is still lower than the average of the European Union or the old European countries. In addition, the analysis of the government expenditure structure revealed that the patterns of government spending in the 
Eastern Europe welfare states are more similar to each other, compared with the Central Europe welfare model.

\section{Conclusion}

The main task of the welfare state is to ensure high standards of living and social protection. Ensuring public welfare is still a very important issue, therefore, the concept of welfare state is widely investigated. The countries choose how to implement this goal, and depending on the policies pursued, different welfare regimes could be distinguished. There are three classic welfare state models: the Liberal, the Conservative and the Social democratic. However, incorporating more diverse countries into research, it is apparent that besides them, Mediterranean and Eastern and Central Europe models prevail. This implies the conclusion that a successful analysis of welfare state is determined by the choice of appropriate indicators and countries.

A hierarchical cluster analysis has revealed that the 29 European countries analyzed are optimally divided into five clusters. The first consists of the Mediterranean, the second the small European states, the third one - the old European countries. The Central and Eastern European countries form two separate welfare state models. The Eastern Europe welfare model consists of Lithuania, Latvia, Estonia, Bulgaria and Romania, and the Central Europe welfare model - Czech Republic, Croatia, Poland, Slovenia, Slovakia and Hungary.

The results of hierarchical cluster analysis have highlighted the need for additional and deeper analysis. The especially controversial attribution of Luxembourg and Malta to one welfare state model implies the need for further research. Taking into account that the aim of this study was to examine the Central and Eastern European welfare state, it is proposed to analyze the case of Luxembourg and Malta in other studies.

The study discovered that the Central Europe welfare model is more similar to the Mediterranean countries, while the Eastern Europe welfare model is very different from all the other welfare state models. Comparing the two models above, it has been observed that the Eastern Europe welfare model has lower labor market flexibility and higher inequality between women's and men's unemployment.

It should also be noted that the social contributions as a share of GDP are lower in the Eastern Europe welfare model, while with less financial resources, these countries are less capable to generate welfare by increasing spending to social protection, education, health care and other sensitive areas.

Meanwhile, while investigating the situation of the Central and Eastern Europe countries in the European context, it was observed that the Central Europe welfare model is closer to the old European countries, compared with the Eastern Europe welfare model.

\section{References}

Addessi, W. (2014). The productivity effect of permanent and temporary labor contracts in the Italian manufacturing sector. Economic Modelling, 36, 666-672.

Androniceanu, A., Popescu, C. R.(2017). An inclusive model for an effective development of the renewable energies public sector. Administratie si Management Public, (28), 81-96.

Arts, W., Gelissen, J. (2002). Three worlds of welfare capitalism or more? A state-of-the-art report. Journal of European Social Policy, 12(2), 137-158.

Bambra, C. (2005). Cash versus services: „worlds of welfare“ and the decommodification of cash benefits and health care services. Journal of social policy, 34(2), 195-213. 
Bartkowiak-Bakun, N. (2017). The diversity of socioeconomic development of rural areas in Poland in The Western Borderland and the problem of post-state farm localities. Oeconomia Copernicana, 8(3), 417-432. doi: https://doi.org/10.24136/oc.v8i3.26.

Becerra-Alonso, D., Androniceanu, A., Georgescu, I. (2016). Sensitivity and vulnerability of European countries in time of crisis based on a new approach to data clustering and curvilinear analysis. Administratie si Management Public, (27), 46-61.

Beg, M., Basarac Sertic, M., Druzic, I. (2017). Determinants of Deindustrialisation in Developed European and Post-Communist Countries. Montenegrin Journal of Economics, 13(2), 93-106.

Burke, S. A., Normand, C., Barry, S., Thomas, S. (2016). From universal health insurance to universal healthcare? The shifting health policy landscape in Ireland since the economic crisis. Health Policy, 120, 235-240.

Calinescu, T., Likhonosova, G., Zelenko, O. (2018). Estimation of Conditions the Realization of Democratic Mechanisms the Transformation of Society: Tearing Away and Social Dialog. Montenegrin Journal of Economics, 14(1), 93-107.

Dacko-Pikiewicz, Z., Walancik, M. (2016). The economic or social dimension of lifelong learning? Forum Scientiae Oeconomia, 4(2), 13-25.

Draskovic, M. (2017). Possibilities and limitations of neo-institutional economic theory in explaining the transition crisis: The case of Montenegro. Transformations in Business \& Economics, 16(3), 164-174.

Draskovic, V., Popov, E., Peleckis, K. K. (2017). Modelling of Institutional Changes in Transition Countries - the Gap Between the Theory and Practice. Montenegrin Journal of Economics, 13(1), 125-140.

Esping-Andersen, G. (1995). The Three Worlds of Welfare Capitalism. Cambridge: Polity Press.

Fenger, H. J. M. (2007). Welfare regimes in Central and Eastern Europe: Incorporating postcommunist countries in a welfare regime typology. Contemporary Issues and Ideas in Social Sciences, 3(2), 1-30.

Khouri, S., Cehlar, M., Horansky, K., Sandorova, K. (2017). Expected life expectancy and its determinants in selected European countries. Transformations in Business \& Economics, 16(2B), 638-655.

Korpi, W., Palme J. (1998). The Paradox of Redistribution and Strategies of Equality: Welfare State Institutions, Inequality and Poverty in the Western Countries. American Sociological Review, 63(5), 661-687.

Mačerinskienè, I., Aleknavičiūtè, R. (2017). National intellectual capital influence on economic growth in the European Union countries. Equilibrium. Quarterly Journal of Economics and Economic Policy, 12(4), 573-592. doi: https://doi.org/10.24136/eq.v12i4.30.

Malo, M. A., Cueto, B. (2013). Temporary Contracts across Generations: Long-term effects of a labour market reform at the margin. Cuadernos de economia, 36, 84-99.

Małkowska, A., Głuszak, M. (2016). Pro-investment local policies in the area of real estate economics - similarities and differences in the strategies used by communes. Oeconomia Copernicana, 7(2), 269-283. doi: https://doi.org/10.12775/OeC.2016.016.

Meyer, D. F., Masehla, T. M., Kot, S. (2017). The Relationship Between Economic Growth and Regional Assessment in South Africa. Journal of Advanced Research in Law and Economics, 8(4), 1377-1385.

McMenamin, I. (2003). Is there an East-Central European Variety of Democratic Capitalism. A Twenty-Two Country Cluster Analysis. Working Paper, 5. Dublin: Dublin City University. 
Novickyte, L, Rabikauskaite, V (2017). The evaluation of the II pillar pension's funds: an integrated approach using multi-criteria decision methods. Business: Theory and Practice, 18(1), 109-127. https://doi.org/10.3846/btp.2017.012

Pilc, M. (2017). Cultural, political and economic roots of the labor market institutional framework in the OECD and post-socialist countries. Equilibrium. Quarterly Journal of Economics and Economic Policy, 12(4), 713-731. doi: https://doi.org/10.24136/eq.v12i4.37.

Rhodes, M. (1996). Southern European Welfare States: Identity, Problems and Prospects for Reform. South European Society and Politics, 1(3), 1-22.

Saint-Arnaud, S., Bernard, P. (2003). Convergence or Resilience? A Hierarchical Cluster Analysis of the Welfare Regimes in Advanced Countries. Current Sociology, 51(5), 499-527.

Sapir, A. (2006). Globalization and the Reform of European Social Models. JCMS, 44(2), 369-390.

Soede, A. J., Vrooman, J. C., Ferraresi, P. M., Segre, G. (2004). Unequal Welfare States. The Hague: Social and Cultural Planning Office.

Szyja, P. (2016). The role of the state in creating green economy. Oeconomia Copernicana, 7(2), 207-222. doi: https://doi.org/10.12775/OeC.2016.013.

Štefko, R., Jenčová, S., Litavcová, E., Vašaničová, P. (2017). Management and funding of the healthcare system. Polish Journal of Management Studies, 16(2), 266-277.

Titmuss, R. M. (1974). What is Social Policy? In: Welfare States: Construction, Deconstruction, Reconstruction Volume I, ed. Leibfried, S., Mau, S. (2008). Edward Elgar Publishing Ltd.

Ushakov, D., Bandurina, N., Shkodinsky, S. (2017). Country's Welfare as an Efficiency Factor in Fiscal Policy Promoting Economig Growth. Montenegrin Journal of Economics, 13(2), 121-127. 
Appendix

Table A1. Voter Turnout at National and European Elections, \% (2014)

\begin{tabular}{|c|c|c|}
\hline No & Country & Voter turnout \\
\hline 1. & Ireland & $70.0^{* * *}$ \\
\hline 2. & Austria & $74.9^{*}$ \\
\hline 3. & Belgium & 89.4 \\
\hline 4. & Bulgaria & 51.1 \\
\hline 5. & The Czech Republic & $59.5^{*}$ \\
\hline 6. & Denmark & $87.7^{* *}$ \\
\hline 7. & Estonia & $63.5^{* *}$ \\
\hline 8. & Greece & $62.5^{* * *}$ \\
\hline 9. & Spain & $68.9^{* *}$ \\
\hline 10. & Italy & $75.2^{*}$ \\
\hline 11. & The United Kingdom & $65.8^{* * * * *}$ \\
\hline 12. & Cyprus & $81.6^{*}$ \\
\hline 13. & Croatia & $54.2^{* *}$ \\
\hline 14. & Latvia & 58.8 \\
\hline 15. & Poland & $48.9^{* * * *}$ \\
\hline 16. & Lithuania & $52.9^{* *}$ \\
\hline 17. & Luxemburg & $91.1^{*}$ \\
\hline 18. & Malta & $93.0^{*}$ \\
\hline 19. & The Netherlands & $74.6^{* *}$ \\
\hline 20. & Norway & 78.2 \\
\hline 21. & Portugal & $58.0^{* * * *}$ \\
\hline 22. & France & $80.4^{* * *}$ \\
\hline 23. & Romania & 64.1 \\
\hline 24. & Slovakia & $59.1^{* *}$ \\
\hline 25. & Slovenia & 51.7 \\
\hline 26. & Finland & $67.4^{* * * *}$ \\
\hline 27. & Sweden & 85.8 \\
\hline 28. & Hungary & 61.8 \\
\hline 29. & Germany & $71.5^{*}$ \\
\hline
\end{tabular}

* 2013 data

** 2011 data

$* * * 2012$ data

**** 2010 data

Source: created by the authors based on Eurostat data. 
Table A2. Economic Situation Variables (2014)

\begin{tabular}{|c|c|c|c|c|c|}
\hline No & Country & $\begin{array}{c}\text { Export } \\
\text { (\% of GDP) }\end{array}$ & $\begin{array}{c}\text { Import } \\
(\% \text { of GDP) }\end{array}$ & $\begin{array}{l}\text { Real GDP } \\
\text { growth, \% }\end{array}$ & $\begin{array}{c}\text { Harmonized } \\
\text { Consumer Price } \\
\text { Index } \\
\end{array}$ \\
\hline 1. & Ireland & 113.79 & 95.87 & 8.5 & 100 \\
\hline 2. & Austria & 53.02 & 49.72 & 0.6 & 99.2 \\
\hline 3. & Belgium & 84.01 & 83.12 & 1.3 & 99.38 \\
\hline 4. & Bulgaria & 65.11 & 65.98 & 1.5 & 101.08 \\
\hline 5. & The Czech Republic & 82.55 & 76.18 & 2.7 & 99.8 \\
\hline 6. & Denmark & 53.38 & 47.32 & 1.3 & 99.8 \\
\hline 7. & Estonia & 83.91 & 80.49 & 2.9 & 99.93 \\
\hline 8. & Greece & 32.69 & 35.24 & 0.7 & 101.11 \\
\hline 9. & Spain & 32.55 & 30.05 & 1.4 & 100.63 \\
\hline 10. & Italy & 29.54 & 26.63 & -0.3 & 99.9 \\
\hline 11. & The United Kingdom & 28.07 & 30.06 & 3.1 & 100 \\
\hline 12. & Cyprus & 60.01 & 59.31 & -2.5 & 101.57 \\
\hline 13. & Croatia & 46.28 & 44.24 & -0.4 & 100.26 \\
\hline 14. & Latvia & 59.50 & 61.75 & 2.4 & 99.79 \\
\hline 15. & Poland & 47.46 & 46.17 & 3.3 & 100.7 \\
\hline 16. & Lithuania & 81.22 & 79.29 & 3.0 & 100.68 \\
\hline 17. & Luxemburg & 203.27 & 170.88 & 4.1 & 99.94 \\
\hline 18. & Malta & 148.46 & 140.43 & 3.5 & 98.84 \\
\hline 19. & The Netherlands & 82.57 & 71.72 & 1.4 & 99.79 \\
\hline 20. & Norway & 38.66 & 29.47 & 2.2 & 98 \\
\hline 21. & Portugal & 40.04 & 39.67 & 0.9 & 99.5 \\
\hline 22. & France & 28.95 & 30.93 & 0.6 & 99.91 \\
\hline 23. & Romania & 41.22 & 41.53 & 3.0 & 100.41 \\
\hline 24. & Slovakia & 76.53 & 68.66 & 2.5 & 100.35 \\
\hline 25. & Slovenia & 91.85 & 88.20 & 3.0 & 100.76 \\
\hline 26. & Finland & 37.68 & 38.62 & -0.7 & 100.16 \\
\hline 27. & Sweden & 44.50 & 40.85 & 2.3 & 99.3 \\
\hline 28. & Hungary & 89.25 & 81.99 & 3.7 & 99.94 \\
\hline 29. & Germany & 45.73 & 38.99 & 1.6 & 99.9 \\
\hline
\end{tabular}

Source: created by the authors based on Eurostat data. 
Table A3. Social Situation Variables - Demographic Situation and Living Conditions (2014)

\begin{tabular}{|c|c|c|c|c|c|c|c|}
\hline No & Country & $\begin{array}{c}\text { Infant } \\
\text { mortality }\end{array}$ & $\begin{array}{c}\text { Life } \\
\text { expectance }\end{array}$ & Birth rate & $\begin{array}{c}\text { People at risk } \\
\text { of poverty or } \\
\text { social } \\
\text { exclusion, \% }\end{array}$ & $\begin{array}{c}\text { Aggregated } \\
\text { replacement } \\
\text { rate }\end{array}$ & $\begin{array}{c}\text { Income } \\
\text { inequality, } \\
\text { S80/S20 }\end{array}$ \\
\hline 1. & Ireland & 3.3 & 81.4 & 1.94 & 27.6 & 0.38 & 4.8 \\
\hline 2. & Austria & 3.0 & 81.7 & 1.47 & 19.2 & 0.60 & 4.1 \\
\hline 3. & Belgium & 3.4 & 81.4 & 1.74 & 21.2 & 0.47 & 3.8 \\
\hline 4. & Bulgaria & 7.6 & 74.5 & 1.53 & 40.1 & 0.44 & 6.8 \\
\hline 5. & $\begin{array}{l}\text { Czech } \\
\text { Republic }\end{array}$ & 2.4 & 78.9 & 1.53 & 14.8 & 0.55 & 3.5 \\
\hline 6. & Denmark & 4.0 & 80.7 & 1.69 & 17.9 & 0.45 & 4.1 \\
\hline 7. & Estonia & 2.7 & 77.4 & 1.54 & 26.0 & 0.47 & 6.5 \\
\hline 8. & Greece & 3.8 & 81.5 & 1.30 & 36.0 & 0.60 & 6.5 \\
\hline 9. & Spain & 2.8 & 83.3 & 1.32 & 29.2 & 0.60 & 6.8 \\
\hline 10. & Italy & 2.8 & 83.2 & 1.37 & 28.3 & 0.64 & 5.8 \\
\hline 11. & $\begin{array}{l}\text { United } \\
\text { Kingdom }\end{array}$ & 3.9 & 81.4 & 1.81 & 24.1 & 0.50 & 5.1 \\
\hline 12. & Cyprus & 1.4 & 82.8 & 1.31 & 27.4 & 0.39 & 5.4 \\
\hline 13. & Croatia & 5.0 & 77.9 & 1.46 & 29.3 & 0.40 & 5.1 \\
\hline 14. & Latvia & 3.8 & 74.5 & 1.65 & 32.7 & 0.44 & 6.5 \\
\hline 15. & Poland & 4.2 & 77.8 & 1.32 & 24.7 & 0.63 & 4.9 \\
\hline 16. & Lithuania & 3.9 & 74.7 & 1.63 & 27.3 & 0.45 & 6.1 \\
\hline 17. & Luxemburg & 2.8 & 82.3 & 1.50 & 19.0 & 0.85 & 4.4 \\
\hline 18. & Malta & 5.0 & 82.1 & 1.42 & 23.8 & 0.56 & 4.0 \\
\hline 19. & Netherlands & 3.6 & 81.8 & 1.71 & 16.5 & 0.50 & 3.8 \\
\hline 20. & Norway & 2.4 & 82.2 & 1.75 & 13.5 & 0.59 & 3.4 \\
\hline 21. & Portugal & 2.9 & 81.3 & 1.23 & 27.5 & 0.63 & 6.2 \\
\hline 22. & France & 3.5 & 82.8 & 2.01 & 18.5 & 0.69 & 4.3 \\
\hline 23. & Romania & 8.4 & 75.0 & 1.52 & 39.5 & 0.64 & 7.2 \\
\hline 24. & Slovakia & 5.8 & 77.0 & 1.37 & 18.4 & 0.62 & 3.9 \\
\hline 25. & Slovenia & 1.8 & 81.2 & 1.58 & 20.4 & 0.45 & 3.7 \\
\hline 26. & Finland & 2.2 & 81.3 & 1.71 & 17.3 & 0.51 & 3.6 \\
\hline 27. & Sweden & 2.2 & 82.3 & 1.88 & 16.9 & 0.60 & 3.9 \\
\hline 28. & Hungary & 4.5 & 76.0 & 1.44 & 31.8 & 0.62 & 4.3 \\
\hline 29. & Germany & 3.2 & 81.2 & 1.47 & 20.6 & 0.45 & 5.1 \\
\hline
\end{tabular}

Source: created by the authors based on Eurostat data. 
Table A4. Social Situation Variables - Education (2014)

\begin{tabular}{|c|c|c|c|c|c|}
\hline No & Country & $\begin{array}{c}\text { Four-years-old } \\
\text { in education } \\
\text { institutions, \% }\end{array}$ & $\begin{array}{l}\text { 20-24 years old } \\
\text { students in } \\
\text { tertiary } \\
\text { education, \% }\end{array}$ & $\begin{array}{l}25-64 \text { years old } \\
\text { with at least } \\
\text { upper secondary } \\
\text { education, } \%\end{array}$ & $\begin{array}{c}\text { Premature school } \\
\text { leaving, } \%\end{array}$ \\
\hline 1. & Ireland & 56.3 & 36.9 & 78.8 & 6.9 \\
\hline 2. & Austria & 91.5 & 29.3 & 83.9 & 7.0 \\
\hline 3. & Belgium & 98.0 & 36.1 & 73.6 & 9.8 \\
\hline 4. & Bulgaria & 80.4 & 36.1 & 81.1 & 12.9 \\
\hline 5. & Czech Republic & 83.6 & 37.3 & 93.2 & 5.5 \\
\hline 6. & Denmark & 97.2 & 37.7 & 79.6 & 7.8 \\
\hline 7. & Estonia & 90.8 & 33.1 & 91.2 & 11.4 \\
\hline 8. & Greece & 48.7 & 38.0 & 68.4 & 9.0 \\
\hline 9. & Spain & 97.2 & 37.7 & 56.6 & 21.9 \\
\hline 10. & Italy & 96.1 & 32.0 & 59.3 & 15.0 \\
\hline 11. & $\begin{array}{l}\text { United } \\
\text { Kingdom }\end{array}$ & 95.1 & 24.2 & 79.2 & 11.8 \\
\hline & Cyprus & 73.2 & 22.8 & 77.6 & 6.8 \\
\hline & Croatia & 58.2 & 38.8 & 82.9 & 2.7 \\
\hline & Latvia & 90.3 & 36.0 & 89.5 & 8.5 \\
\hline & Poland & 71.5 & 41.8 & 90.5 & 5.4 \\
\hline 16. & Lithuania & 83.3 & 41.4 & 93.3 & 5.9 \\
\hline 17. & Luxemburg & 97.8 & 9.5 & 82.0 & 6.1 \\
\hline & Malta & 97.5 & 20.8 & 42.2 & 20.3 \\
\hline 19. & Netherlands & 96.1 & 36.7 & 75.9 & 8.7 \\
\hline & Norway & 97.0 & 35.0 & 82.7 & 11.7 \\
\hline 21. & Portugal & 90.6 & 31.0 & 43.3 & 17.4 \\
\hline 22. & France & 100.3 & 32.4 & 76.7 & 9.0 \\
\hline 23. & Romania & 85.0 & 28.3 & 72.8 & 18.1 \\
\hline 24. & Slovakia & 73.8 & 31.8 & 91.0 & 6.7 \\
\hline 25. & Slovenia & 88.7 & 47.3 & 85.7 & 4.4 \\
\hline 26. & Finland & 73.9 & 35.1 & 86.5 & 9.5 \\
\hline 27. & Sweden & 94.6 & 26.7 & 83.7 & 6.7 \\
\hline 28. & Hungary & 93.8 & 28.4 & 83.1 & 11.4 \\
\hline 29. & Germany & 96.7 & 28.4 & 86.9 & 9.5 \\
\hline
\end{tabular}

Source: created by the authors based on Eurostat data. 
Table A5. Social Situation Variables - Labor Market (2014)

\begin{tabular}{|c|c|c|c|c|c|c|c|c|c|}
\hline No & Country & $\begin{array}{l}\text { Employ } \\
\text { ment }\end{array}$ & $\begin{array}{c}\text { Youth } \\
\text { employment } \\
\text { (15-24 years } \\
\text { old) }\end{array}$ & $\begin{array}{c}\text { Elderly } \\
\text { employment } \\
\text { (55-64 } \\
\text { years old) }\end{array}$ & $\begin{array}{c}\text { Workers } \\
\text { under } \\
\text { temporary } \\
\text { contracts, } \\
\% \\
\end{array}$ & $\begin{array}{c}\text { Part } \\
\text { time } \\
\text { workers, } \\
\%\end{array}$ & $\begin{array}{c}\text { Self- } \\
\text { employed, } \\
\%\end{array}$ & $\begin{array}{l}\text { Long term } \\
\text { unemploy } \\
\text { ment }\end{array}$ & $\begin{array}{l}\text { Unemp- } \\
\text { loyment }\end{array}$ \\
\hline 1. & Ireland & 67.0 & 28.4 & 53.0 & 7.7 & 23.0 & 15.2 & 59.2 & 11.3 \\
\hline 2. & Austria & 74.2 & 52.1 & 45.1 & 8.1 & 26.9 & 10.9 & 27.2 & 5.6 \\
\hline 3. & Belgium & 67.3 & 23.2 & 42.7 & 7.4 & 23.7 & 13.2 & 49.9 & 8.5 \\
\hline 4. & Bulgaria & 65.1 & 20.7 & 50.0 & 4.6 & 2.5 & 11.5 & 60.3 & 11.4 \\
\hline 5. & $\begin{array}{l}\text { Czech } \\
\text { Republic }\end{array}$ & 73.5 & 27.1 & 54.0 & 8.0 & 5.5 & 17.0 & 43.6 & 6.1 \\
\hline 6. & Denmark & 75.9 & 53.7 & 63.2 & 7.9 & 24.6 & 8.0 & 25.2 & 6.6 \\
\hline 7. & Estonia & 74.3 & 33.3 & 64.0 & 2.8 & 8.3 & 8.8 & 45.2 & 7.4 \\
\hline 8. & Greece & 53.3 & 13.3 & 34.0 & 7.5 & 9.3 & 30.7 & 73.4 & 26.5 \\
\hline 9. & Spain & 59.9 & 16.7 & 44.3 & 19.9 & 15.8 & 16.7 & 52.8 & 24.5 \\
\hline 10. & Italy & 59.9 & 15.6 & 46.2 & 10.4 & 18.1 & 22.2 & 61.4 & 12.7 \\
\hline 11. & $\begin{array}{l}\text { United } \\
\text { Kingdom }\end{array}$ & 76.2 & 48.1 & 61.0 & 5.4 & 25.3 & 14.0 & 35.7 & 6.1 \\
\hline 12. & Cyprus & 67.6 & 25.8 & 46.9 & 15.8 & 13.5 & 15.2 & 47.7 & 16.1 \\
\hline 13. & Croatia & 59.2 & 18.3 & 36.2 & 14.4 & 5.3 & 13.4 & 58.5 & 17.3 \\
\hline 14. & Latvia & 70.7 & 32.5 & 56.4 & 2.9 & 6.8 & 10.6 & 43.0 & 10.8 \\
\hline 15. & Poland & 66.5 & 25.8 & 42.5 & 22.4 & 7.1 & 17.9 & 42.7 & 9.0 \\
\hline 16. & Lithuania & 71.8 & 27.6 & 56.2 & 2.4 & 8.6 & 10.6 & 44.6 & 10.7 \\
\hline 17. & Luxemburg & 72.1 & 20.4 & 42.5 & 7.3 & 18.4 & 7.8 & 27.3 & 6.0 \\
\hline 18. & Malta & 66.4 & 46.2 & 37.8 & 6.7 & 15.5 & 13.2 & 46.9 & 5.8 \\
\hline 19. & $\begin{array}{l}\text { The } \\
\text { Netherlands }\end{array}$ & 75.4 & 58.8 & 59.9 & 17.7 & 49.6 & 15.2 & 39.4 & 7.4 \\
\hline 20. & Norway & 79.6 & 50.1 & 72.2 & 7.3 & 25.6 & 6.6 & 23.0 & 3.5 \\
\hline 21. & Portugal & 67.6 & 22.4 & 47.8 & 18.0 & 10.1 & 15.5 & 59.5 & 14.1 \\
\hline 22. & France & 69.4 & 27.9 & 46.9 & 14.2 & 18.6 & 10.8 & 44.2 & 10.3 \\
\hline 23. & Romania & 65.7 & 22.5 & 43.1 & 1.1 & 8.7 & 18.4 & 41.1 & 6.8 \\
\hline 24. & Slovakia & 65.9 & 21.8 & 44.8 & 7.4 & 5.1 & 15.2 & 70.2 & 13.2 \\
\hline 25. & Slovenia & 67.7 & 26.8 & 35.4 & 13.7 & 10.0 & 12.1 & 54.5 & 9.7 \\
\hline 26. & Finland & 73.1 & 41.4 & 59.1 & 13.4 & 14.1 & 12.6 & 22.4 & 8.7 \\
\hline 27. & Sweden & 80.0 & 42.8 & 74.0 & 15.2 & 24.5 & 9.1 & 19.0 & 7.9 \\
\hline 28. & Hungary & 66.7 & 23.5 & 41.7 & 9.6 & 6.0 & 10.3 & 47.4 & 7.7 \\
\hline 29. & Germany & 77.7 & 46.1 & 65.6 & 11.8 & 26.5 & 9.8 & 44.3 & 5.0 \\
\hline
\end{tabular}

Source: created by the authors based on Eurostat data. 
Table A6. Social Situation Variables - Gender Differences in Labor Market (2014)

\begin{tabular}{|c|c|c|c|c|c|}
\hline No & Country & $\begin{array}{l}\text { The ratio of } \\
\text { employment } \\
\text { rates of men } \\
\text { and women }\end{array}$ & $\begin{array}{c}\text { The ratio of } \\
\text { unemployment } \\
\text { rates of men and } \\
\text { women }\end{array}$ & $\begin{array}{c}\text { The ratio of } \\
\text { unemployment } \\
\text { rates of men and } \\
\text { women }\end{array}$ & $\begin{array}{l}\text { The pay gap } \\
\text { between men } \\
\text { and women, \% }\end{array}$ \\
\hline 1. & Ireland & $0.80^{*}$ & 1.37 & 1.33 & 14.4 \\
\hline 2. & Austria & 0.89 & 1.09 & 1.10 & 22.9 \\
\hline 3. & Belgium & 0.87 & 1.14 & 1.10 & 9.9 \\
\hline 4. & Bulgaria & 0.89 & 1.18 & 1.09 & 13.4 \\
\hline 5. & Czech Republic & 0.81 & 0.69 & 1.01 & 22.1 \\
\hline 6. & Denmark & 0.91 & 0.94 & 1.06 & 15.8 \\
\hline 7. & Estonia & 0.89 & 1.16 & 1.30 & 28.3 \\
\hline 8. & Greece & $0.77^{* *}$ & 0.78 & 0.98 & 15.0 \\
\hline 9. & Spain & 0.86 & 0.93 & 0.97 & 18.8 \\
\hline 10. & Italy & 0.74 & 0.86 & 0.96 & 6.5 \\
\hline 11. & United Kingdom & 0.86 & 1.10 & 1.33 & 18.3 \\
\hline 12. & Cyprus & 0.87 & 1.13 & 1.04 & 15.4 \\
\hline 13. & Croatia & 0.86 & 0.90 & 0.99 & 10.4 \\
\hline 14. & Latvia & 0.92 & 1.20 & 1.10 & 15.2 \\
\hline 15. & Poland & 0.82 & 0.89 & 1.00 & 7.7 \\
\hline 16. & Lithuania & 0.93 & 1.33 & 0.98 & 14.8 \\
\hline & Luxemburg & 0.84 & 0.91 & 0.97 & 8.6 \\
\hline & Malta & 0.64 & 1.15 & 1.43 & 4.5 \\
\hline 19. & The Netherlands & 0.87 & 0.92 & 1.02 & 16.2 \\
\hline 20. & Norway & 0.94 & 1.12 & $1.11^{* * *}$ & 14.9 \\
\hline 21. & Portugal & 0.91 & 0.95 & 1.04 & 14.5 \\
\hline & France & 0.89 & 1.05 & 1.05 & 15.3 \\
\hline 23. & Romania & 0.77 & 1.20 & 1.05 & 10.1 \\
\hline & Slovakia & 0.81 & 0.94 & 1.09 & 21.1 \\
\hline 25. & Slovenia & 0.90 & 0.85 & 1.02 & 2.9 \\
\hline & Finland & 0.96 & 1.16 & 1.23 & 18.0 \\
\hline 27. & Sweden & 0.94 & 1.06 & 1.17 & 14.6 \\
\hline & Hungary & 0.82 & 0.96 & 1.02 & 15.1 \\
\hline 29. & Germany & 0.88 & 1.15 & 1.10 & 21.6 \\
\hline
\end{tabular}

* calculations based on 2012 data

** calculations based on 2010 data

*** calculations based on 2013 data

Source: created by the authors based on Eurostat data. 
Table A7. Government Program Variables (2014)

\begin{tabular}{|c|c|c|c|c|c|c|c|c|c|}
\hline \multirow[b]{2}{*}{ No } & \multirow[b]{2}{*}{ Country } & \multirow[b]{2}{*}{$\begin{array}{c}\text { Social } \\
\text { contributions, } \\
\% \text { of GDP }\end{array}$} & \multicolumn{4}{|c|}{$\begin{array}{c}\text { Government expenditure, } \\
\% \text { of GDP }\end{array}$} & \multicolumn{3}{|c|}{$\begin{array}{l}\text { Expenditure for social protection, by } \\
\text { function, } \% \text { of the total expenditure }\end{array}$} \\
\hline & & & 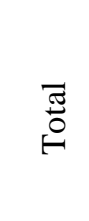 & 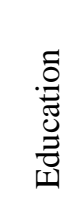 & 吾 & 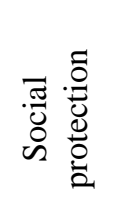 & 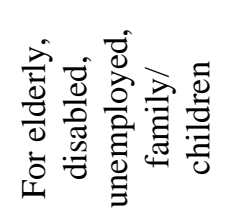 & 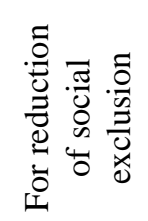 & 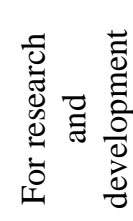 \\
\hline 1. & Ireland & 5.8 & 38.3 & 4.3 & 7.6 & 13.2 & $57.83^{*}$ & $0.9^{*}$ & 1.52 \\
\hline 2. & Austria & 15.4 & 52.7 & 5.0 & 7.9 & 21.7 & $64.65^{*}$ & $1.46^{*}$ & 2.99 \\
\hline 3. & Belgium & 16.7 & 55.1 & 6.3 & 8.1 & 19.9 & $58.07^{*}$ & $2.75^{*}$ & 0.8 \\
\hline 4. & Bulgaria & 7.9 & 42.1 & 4.1 & 5.5 & 13.4 & $64.38^{*}$ & $1.45^{*}$ & 0.8 \\
\hline 5. & Czech Republic & 14.8 & 42.6 & 5.2 & 7.7 & 13.2 & $61.1^{*}$ & $1.54^{*}$ & 2.0 \\
\hline 6. & Denmark & 1.1 & 56 & 7.2 & 8.7 & 24.5 & $64.92^{*}$ & $4.03^{*}$ & 3.05 \\
\hline 7. & Estonia & 11.1 & 38 & 5.6 & 5.1 & 11.8 & $69.71^{*}$ & $0.7^{*}$ & 1.44 \\
\hline 8. & Greece & 13.6 & 49.9 & 4.4 & 4.7 & 20.1 & $64.86^{* *}$ & $2.05^{* *}$ & 0.84 \\
\hline 9. & Spain & 12.5 & 44.5 & 4.1 & 6.1 & 17.6 & $62.3^{*}$ & $0.91^{*}$ & 1.23 \\
\hline 10. & Italy & 13.3 & 51.2 & 4.1 & 7.2 & 21.4 & $63.65^{*}$ & $0.64^{*}$ & 1.29 \\
\hline 11. & $\begin{array}{l}\text { The United } \\
\text { Kingdom }\end{array}$ & 7.6 & 43.9 & 5.2 & 7.6 & 16.5 & $60.61^{*}$ & $2.64^{*}$ & 1.7 \\
\hline 12. & Cyprus & 8.3 & 48.7 & 5.8 & 2.7 & 12.2 & $64.79^{*}$ & $4.84^{*}$ & 0.48 \\
\hline 13. & Croatia & 11.8 & 48.2 & 4.7 & 6.7 & 15.7 & $53.35^{*}$ & $0.21^{*}$ & 0.79 \\
\hline 14. & Latvia & 8.7 & 37.3 & 5.9 & 3,8 & 11.5 & $72.98^{*}$ & $0.99^{*}$ & 0.69 \\
\hline 15. & Poland & 13.2 & 42.1 & 5.3 & 4.6 & 16.1 & $62.36^{* *}$ & $0.75^{* *}$ & 0.94 \\
\hline 16. & Lithuania & 11.5 & 34.8 & 5.4 & 5.5 & 11.5 & $61.06^{*}$ & $3.98^{*}$ & 1.01 \\
\hline 17. & Luxemburg & 12.3 & 42.4 & 5.2 & 5.0 & 18.6 & $61.65^{*}$ & $2.11^{*}$ & 1.26 \\
\hline 18. & Malta & 6.9 & 43.1 & 5.8 & 6.0 & 13.7 & $57.55^{*}$ & $1.39^{*}$ & 0.83 \\
\hline 19. & Netherlands & 15.4 & 46.2 & 5.4 & 8.1 & 16.9 & $50.88^{*}$ & $4.9^{*}$ & 1.97 \\
\hline 20. & Norway & 9.9 & 45.6 & 5.1 & 7.8 & 18.1 & $64.04^{*}$ & $2.72^{*}$ & 1.71 \\
\hline 21. & Portugal & 11.7 & 51.7 & 6.2 & 6.2 & 18.5 & $64.16^{*}$ & $0.86^{*}$ & 1.29 \\
\hline 22. & France & 19.1 & 57.5 & 5.5 & 8,2 & 24.8 & $57.1^{*}$ & $2.36^{*}$ & 2.26 \\
\hline 23. & Romania & 8.6 & 34.9 & 3.0 & 4.0 & 11.4 & $65.79^{*}$ & $1.11^{*}$ & 0.38 \\
\hline 24. & Slovakia & 13.6 & 41.6 & 4.1 & 1.9 & 20.0 & $59.76^{*}$ & $2.24^{*}$ & 0.89 \\
\hline 25. & Slovenia & 14.6 & 49.8 & 5.9 & 6.6 & 18.0 & $58.82^{*}$ & $2.63^{*}$ & 2.39 \\
\hline 26. & Finland & 12.8 & 58.1 & 6.4 & 8.3 & 25.4 & $66.07^{*}$ & $2.72^{*}$ & 3.17 \\
\hline 27. & Sweden & 3.7 & 51.8 & 6.6 & 7.0 & 21.3 & $67.84^{*}$ & $2.37^{*}$ & 3.16 \\
\hline 28. & Hungary & 13.1 & 49.9 & 5.2 & 5.0 & 15.6 & $67.22^{*}$ & $0.54^{*}$ & 1.37 \\
\hline 29. & Germany & 16.5 & 44.3 & 4.3 & 7.2 & 18.8 & $53.47^{*}$ & $0.61^{*}$ & 2.8 \\
\hline
\end{tabular}

* 2013 data

** 2012 data

Source: created by the authors based on Eurostat data. 
Table A8. The Structure of Government Expenditure, \% (2014)

\begin{tabular}{|c|c|c|c|c|c|c|c|c|c|c|}
\hline Country & 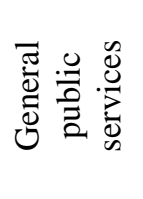 & 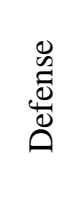 & 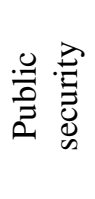 & 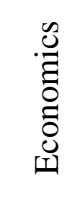 & 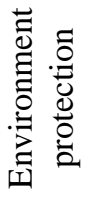 & 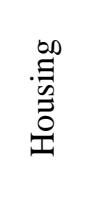 & 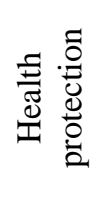 & 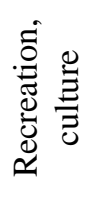 & 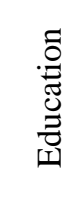 & 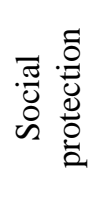 \\
\hline ES 28 & 13.9 & 2.8 & 3.7 & 8.8 & 1.7 & 1.4 & 15.0 & 2.1 & 10.2 & 40.4 \\
\hline Ireland & 15.9 & 0.9 & 3.7 & 8.4 & 1.5 & 1.9 & 19.9 & 2.0 & 11.1 & 34.6 \\
\hline \multicolumn{11}{|c|}{ The Eastern Europe welfare model } \\
\hline Bulgaria & 14.9 & 3.3 & 6.5 & 11.7 & 1.6 & 3.9 & 13.0 & 3.5 & 9.7 & 31.9 \\
\hline Estonia & 10.5 & 4.7 & 5.1 & 12.6 & 1.6 & 1.2 & 13.5 & 5.2 & 14.7 & 31.0 \\
\hline Latvia & 13.2 & 2.4 & 5.4 & 13.1 & 1.8 & 3.0 & 10.2 & 4.5 & 15.8 & 30.7 \\
\hline Lithuania & 13.3 & 3.0 & 4.8 & 9.3 & 1.6 & 1.0 & 15.9 & 2.6 & 15.5 & 33.0 \\
\hline Romania & 13.4 & 2.4 & 6.0 & 17.1 & 2.2 & 3.3 & 11.5 & 2.7 & 8.6 & 32.7 \\
\hline Group average & 13.1 & 3.2 & 5.6 & 12.8 & 1.8 & 2.5 & 12.8 & 3.7 & 12.9 & 31.9 \\
\hline \multicolumn{11}{|c|}{ The Central Europe welfare model } \\
\hline The Czech Republic & 11.3 & 1.7 & 4.0 & 14.4 & 2.5 & 2.1 & 18.0 & 2.8 & 12.2 & 31.1 \\
\hline Croatia & 18.5 & 3.0 & 4.3 & 12.8 & 0.9 & 1.5 & 13.9 & 2.8 & 9.8 & 32.5 \\
\hline Poland & 11.9 & 3.5 & 5.3 & 11.0 & 2.1 & 1.7 & 11.0 & 2.8 & 12.5 & 38.2 \\
\hline Slovakia & 13.6 & 2.2 & 5.4 & 10.8 & 1.7 & 1.5 & 4.5 & 2.2 & 9.9 & 48.1 \\
\hline Slovenia & 15.1 & 1.7 & 3.3 & 11.5 & 2.0 & 1.8 & 13.2 & 3.4 & 11.9 & 36.2 \\
\hline Hungary & 20.4 & 1.2 & 3.9 & 14.8 & 2.4 & 1.8 & 10.0 & 4.0 & 10.3 & 31.2 \\
\hline Group average & 15.1 & 2.2 & 4.4 & 12.6 & 1.9 & 1.7 & 11.8 & 3.0 & 11.1 & 36.2 \\
\hline \multicolumn{11}{|c|}{ The small European states welfare model } \\
\hline Luxemburg & 11.0 & 0.7 & 2.4 & 10.5 & 2.6 & 1.8 & 11.9 & 3.0 & 12.2 & 43.9 \\
\hline Malta & 16.4 & 1.8 & 3.2 & 12.5 & 3.7 & 0.8 & 13.9 & 2.5 & 13.5 & 31.8 \\
\hline Group average & 13.7 & 1.3 & 2.8 & 11.5 & 3.2 & 1.3 & 12.9 & 2.8 & 12.9 & 37.9 \\
\hline \multicolumn{11}{|c|}{ The Mediterranean welfare model } \\
\hline Greece & 19.8 & 5.4 & 4.3 & 7.4 & 3.1 & 0.4 & 9.3 & 1.2 & 8.8 & 40.2 \\
\hline Spain & 15.5 & 1.9 & 4.5 & 9.9 & 1.9 & 1.1 & 13.7 & 2.6 & 9.1 & 39.6 \\
\hline Italy & 17.4 & 2.4 & 3.7 & 8.1 & 1.9 & 1.3 & 14.0 & 1.4 & 7.9 & 41.8 \\
\hline Cyprus & 38.5 & 3.0 & 3.6 & 5.7 & 0.5 & 4.6 & 5.5 & 1.8 & 11.8 & 25.0 \\
\hline Portugal & 16.9 & 1.9 & 4.3 & 13.3 & 0.9 & 1.2 & 12.1 & 1.7 & 12.0 & 35.7 \\
\hline Group average & 21.6 & 2.9 & 4.1 & 8.9 & 1.7 & 1.7 & 10.9 & 1.7 & 9.9 & 36.5 \\
\hline \multicolumn{11}{|c|}{ The old European states welfare model } \\
\hline Austria & 13.0 & 1.1 & 2.6 & 14.1 & 0.9 & 0.7 & 15.0 & 2.3 & 9.4 & 40.9 \\
\hline Belgium & 15.2 & 1.6 & 3.4 & 12.8 & 1.7 & 0.7 & 14.7 & 2.3 & 11.4 & 36.2 \\
\hline Denmark & 12.9 & 2.1 & 1.8 & 6.5 & 0.8 & 0.4 & 15.6 & 3.2 & 12.8 & 43.8 \\
\hline The United Kingdom & 12.2 & 4.9 & 4.6 & 6.8 & 1.9 & 1.4 & 17.3 & 1.5 & 11.8 & 37.5 \\
\hline The Netherlands & 11.3 & 2.4 & 4.1 & 9.1 & 3.2 & 1.0 & 17.4 & 3.2 & 11.7 & 36.5 \\
\hline Norway & 9.6 & 3.2 & 2.2 & 10.6 & 1.8 & 1.5 & 17.1 & 3.1 & 11.2 & 39.6 \\
\hline France & 11.6 & 3.0 & 2.8 & 8.8 & 1.7 & 2.5 & 14.3 & 2.5 & 9.6 & 43.1 \\
\hline Finland & 14.3 & 2.4 & 2.3 & 8.3 & 0.4 & 0.7 & 14.3 & 2.5 & 11.0 & 43.8 \\
\hline Sweden & 15.0 & 2.5 & 2.6 & 8.3 & 0.6 & 1.5 & 13.6 & 2.1 & 12.7 & 41.1 \\
\hline Germany & 14.3 & 2.3 & 3.5 & 7.5 & 1.3 & 0.9 & 16.3 & 1.8 & 9.7 & 42.4 \\
\hline Group average & 12.9 & 2.6 & 3.0 & 9.3 & 1.4 & 1.1 & 15.6 & 2.5 & 11.1 & 40.5 \\
\hline
\end{tabular}

Source: created by the authors based on Eurostat data. 
Table A9. The Structure of Social protection Expenditure, \% (2014)

\begin{tabular}{|c|c|c|c|c|c|c|c|c|}
\hline Country & $\begin{array}{l}\text { Sickness } \\
\text { and } \\
\text { disability }\end{array}$ & $\begin{array}{l}\text { Old } \\
\text { age }\end{array}$ & Widowhood & $\begin{array}{l}\text { Family } \\
\text { and } \\
\text { children }\end{array}$ & $\begin{array}{l}\text { Unemplo } \\
\text { yment }\end{array}$ & Housing & $\begin{array}{c}\text { Social } \\
\text { exclusion }\end{array}$ & Other \\
\hline ES 28 & 5.9 & 21.4 & $\mathrm{n} / \mathrm{d}$ & 3.6 & 3.0 & 1.1 & 1.7 & 0.7 \\
\hline Ireland & 6.3 & 9.6 & 2.4 & 5.8 & 6.5 & 2.4 & 1.4 & 0.2 \\
\hline \multicolumn{9}{|c|}{ The Eastern Europe welfare model } \\
\hline Bulgaria & 0.6 & 23.8 & $\mathrm{n} / \mathrm{d}$ & 6.0 & 0.2 & 0.1 & 0.2 & 1.0 \\
\hline Estonia & 5.2 & 17.6 & 0.2 & 4.6 & 2.6 & 0.1 & 0.3 & 0.5 \\
\hline Latvia & 5.2 & 19.9 & 0.0 & 2.4 & 1.1 & 0.3 & 1.0 & 0.7 \\
\hline Lithuania & 8.1 & 17.7 & 1.0 & 2.8 & 1.1 & 0.2 & 1.7 & 0.4 \\
\hline Romania & 2.3 & 25.7 & 0.2 & 2.4 & 0.5 & 0.0 & 0.8 & 0.6 \\
\hline $\begin{array}{l}\text { Group } \\
\text { average }\end{array}$ & 4.3 & 20.9 & 0.4 & 3.6 & 1.1 & 0.1 & 0.8 & 0.6 \\
\hline \multicolumn{9}{|c|}{ The Central Europe welfare model } \\
\hline $\begin{array}{l}\text { Czech } \\
\text { Republic }\end{array}$ & 5.2 & 18.7 & 1.5 & 2.7 & 0.6 & 0.7 & 1.2 & 0.5 \\
\hline Croatia & 6.1 & 21.9 & 4.3 & 3.3 & 1.3 & 0.1 & 0.7 & 0.4 \\
\hline Poland & 10.3 & 13.9 & 2.8 & 3.1 & 0.8 & 0.1 & 0.7 & 0.9 \\
\hline Slovakia & 17.9 & 17.6 & 2.1 & 3.1 & 0.5 & 0.0 & 1.1 & 5.8 \\
\hline Slovenia & 4.6 & 20.3 & 3.0 & 4.2 & 1.5 & 0.0 & 1.7 & 0.8 \\
\hline Hungary & 6.5 & 15.0 & 2.3 & 4.0 & 1.0 & 0.7 & 1.2 & 0.4 \\
\hline $\begin{array}{l}\text { Group } \\
\text { average }\end{array}$ & 8.4 & 17.9 & 2.7 & 3.4 & 1.0 & 0.3 & 1.1 & 1.5 \\
\hline \multicolumn{9}{|c|}{ The small European states welfare model } \\
\hline Luxemburg & 4.9 & 25.7 & 0.0 & 8.1 & 3.2 & 0.1 & 1.8 & 0.1 \\
\hline Malta & 3.2 & 18.6 & 3.8 & 2.9 & 1.2 & 0.3 & 0.8 & 1.1 \\
\hline $\begin{array}{l}\text { Group } \\
\text { average }\end{array}$ & 4.1 & 22.2 & 1.9 & 5.5 & 2.2 & 0.2 & 1.3 & 0.6 \\
\hline \multicolumn{9}{|c|}{ Mediterranean welfare model } \\
\hline Greece & 3.2 & 30.7 & 3.3 & 1.4 & 1.3 & 0.2 & 0.0 & 0.2 \\
\hline Spain & 5.3 & 20.6 & 5.4 & 1.3 & 5.6 & 0.1 & 0.6 & 0.7 \\
\hline Italy & 3.5 & 27.3 & 5.4 & 2.8 & 2.4 & 0.1 & 0.5 & 0.0 \\
\hline Cyprus & 1.1 & 11.8 & 2.9 & 4.7 & 2.6 & 0.0 & 1.8 & 0.2 \\
\hline Portugal & 2.6 & 23.1 & 3.4 & 2.2 & 3.0 & 0.0 & 0.5 & 1.0 \\
\hline $\begin{array}{l}\text { Group } \\
\text { average }\end{array}$ & 3.1 & 22.7 & 4.1 & 2.5 & 3.0 & 0.1 & 0.7 & 0.4 \\
\hline \multicolumn{9}{|c|}{ The old European states welfare model } \\
\hline Austria & 3.8 & 24.9 & 2.8 & 4.3 & 2.7 & 0.2 & 1.8 & 0.4 \\
\hline Belgium & 5.6 & 16.1 & 3.4 & 4.2 & 4.1 & 0.4 & 2.0 & 0.5 \\
\hline Denmark & 8.9 & 15.0 & 0.0 & 8.6 & 5.6 & 1.3 & 3.3 & 0.9 \\
\hline $\begin{array}{l}\text { The United } \\
\text { Kingdom }\end{array}$ & 6.3 & 19.3 & 0.1 & 3.7 & 0.5 & 3.1 & 3.7 & 0.8 \\
\hline $\begin{array}{l}\text { The } \\
\text { Netherlands }\end{array}$ & 10.2 & 14.8 & 0.3 & 2.1 & 4.0 & 0.9 & 4.2 & 0.1 \\
\hline Norway & 13.6 & 14.2 & 0.4 & 7.4 & 1.0 & 0.3 & 1.7 & 1.1 \\
\hline France & 5.0 & 23.8 & 2.8 & 4.4 & 3.4 & 1.6 & 1.7 & 0.4 \\
\hline Finland & 8.0 & 20.9 & 1.4 & 5.7 & 4.4 & 0.6 & 1.4 & 1.2 \\
\hline Sweden & 8.8 & 21.2 & 0.6 & 4.9 & 2.7 & 0.7 & 2.0 & 0.2 \\
\hline Germany & 6.7 & 20.6 & 4.2 & 3.5 & 4.1 & 1.0 & 0.8 & 1.6 \\
\hline $\begin{array}{l}\text { Group } \\
\text { average }\end{array}$ & 7.7 & 19.1 & 1.6 & 4.9 & 3.3 & 1.0 & 2.3 & 0.7 \\
\hline
\end{tabular}

Source: created by the authors based on Eurostat data. 